\title{
Inorganic carbon fixation by chemosynthetic ectosymbionts and nutritional transfers to the hydrothermal vent host-shrimp Rimicaris exoculata
}

\author{
Julie Ponsard ${ }^{1}$, Marie-Anne Cambon-Bonavita ${ }^{2}$, Magali Zbinden ${ }^{3}$, Gilles Lepoint ${ }^{4}$, \\ André Joassin ${ }^{5}$, Laure Corbari ${ }^{6}$, Bruce Shillito ${ }^{3}$, Lucile Durand ${ }^{2}$, Valérie Cueff-Gauchard ${ }^{2}$ \\ and Philippe Compère ${ }^{1}$ \\ ${ }^{1}$ Laboratoire de Morphologie fonctionnelle et évolutive, Département de Biologie, Ecologie et Evolution, \\ Centre MARE, Université de Liège, Liège, Belgium; ${ }^{2}$ Laboratoire de Microbiologie des Environnements \\ Extrêmes UMR 6197 Ifremer-CNRS-UBO, BP70, Plouzané, France; ${ }^{3}$ Equipe Adaptation aux Milieux Extrêmes, \\ UMR 7138 CNRS, Systématique, Adaptation et Evolution, Université Pierre et Marie Curie, Paris Cedex 05, \\ France; ${ }^{4}$ Laboratoire d'Océanologie, Département Biologie, Ecologie et Evolution, Centre MARE, Université de \\ Liège, Liège, Belgium; ${ }^{5}$ Laboratoire de Chimie de Coordination et Radiochimie, Département de Chimie, \\ Université de Liège, Liège, Belgium and ${ }^{6}$ Equipe Espèces et Spéciation, UMR 7138 CNRS, Systématique, \\ Adaptation et Evolution, Muséum National d'Histoire Naturelle, Paris Cedex 05, France
}

\begin{abstract}
The shrimp Rimicaris exoculata dominates several hydrothermal vent ecosystems of the MidAtlantic Ridge and is thought to be a primary consumer harbouring a chemoautotrophic bacterial community in its gill chamber. The aim of the present study was to test current hypotheses concerning the epibiont's chemoautotrophy, and the mutualistic character of this association. Invivo experiments were carried out in a pressurised aquarium with isotope-labelled inorganic carbon $\left(\mathrm{NaH}^{13} \mathrm{CO}_{3}\right.$ and $\left.\mathrm{NaH}^{14} \mathrm{CO}_{3}\right)$ in the presence of two different electron donors $\left(\mathrm{Na}_{2} \mathrm{~S}_{2} \mathrm{O}_{3}\right.$ and $\left.\mathrm{Fe}^{2+}\right)$ and with radiolabelled organic compounds $\left({ }^{14} \mathrm{C}\right.$-acetate and ${ }^{3} \mathrm{H}$-lysine) chosen as potential bacterial substrates and/or metabolic by-products in experiments mimicking transfer of small biomolecules from epibionts to host. The bacterial epibionts were found to assimilate inorganic carbon by chemoautotrophy, but many of them (thick filaments of epsilonproteobacteria) appeared versatile and able to switch between electron donors, including organic compounds (heterotrophic acetate and lysine uptake). At least some of them (thin filamentous gammaproteobacteria) also seem capable of internal energy storage that could supply chemosynthetic metabolism for hours under conditions of electron donor deprivation. As direct nutritional transfer from bacteria to host was detected, the association appears as true mutualism. Import of soluble bacterial products occurs by permeation across the gill chamber integument, rather than via the digestive tract. This first demonstration of such capabilities in a decapod crustacean supports the previously discarded hypothesis of transtegumental absorption of dissolved organic matter or carbon as a common nutritional pathway. The ISME Journal (2013) 7, 96-109; doi:10.1038/ismej.2012.87; published online 23 August 2012 Subject Category: microbe-microbe and microbe-host interactions

Keywords: autoradiography; chemosynthetic ectosymbiosis; Crustacea; isotopes; Rimicaris exoculata; transtegumental transfer
\end{abstract}

\section{Introduction}

Mostly described as endosymbioses (Dubilier et al., 2008), associations between invertebrates and chemoautotrophic bacteria are regularly encountered in reducing marine habitats (Cavanaugh et al., 2006). Among the Crustacea, chemosynthetic epibioses are

Correspondence: P Compère, Laboratoire de Morphologie fonctionnelle et évolutive, Département de Biologie, Ecologie et Evolution, Centre MARE, Université de Liège, 4000 Sart-Tilman, Liège, Belgium E-mail: pcompere@ulg.ac.be

Received 30 January 2012; revised 18 June 2012; accepted 20 June 2012; published online 23 August 2012 reported in only a few hydrothermal decapods: the shrimp Rimicaris exoculata (Segonzac et al., 1993), the galatheid crabs Kiwa hirsuta (Macpherson et al., 2005; Goffredi et al., 2008), Kiwa puravida (Thurber et al., 2011), and Shinkaia crosnieri (Miyake et al., 2007), and two amphipods from littoral sediments (Gillan and Dubilier, 2004; Gillan et al., 2004) and sulphide-rich caves (Dattagupta et al., 2009). Most of these associations are regarded as nutritional ectosymbioses, but to date, there is little direct evidence of bacterial autotrophy and no direct demonstration of mutualistic nutritional bacteriahost interactions. 
The shrimp $R$. exoculata (Williams and Rona, 1986) dominates the megafauna of several deep-sea hydrothermal vent sites of the Mid-Atlantic Ridge, forms dense aggregates around active chimneys (Segonzac, 1992) and harbours a luxuriant bacterial community in its enlarged gill chamber (Van Dover et al., 1988; Casanova et al., 1993; Segonzac et al., 1993; Polz and Cavanaugh, 1995; Zbinden et al., 2004) (Figure 1). The integument surfaces are periodically re-colonised during the moult cycle
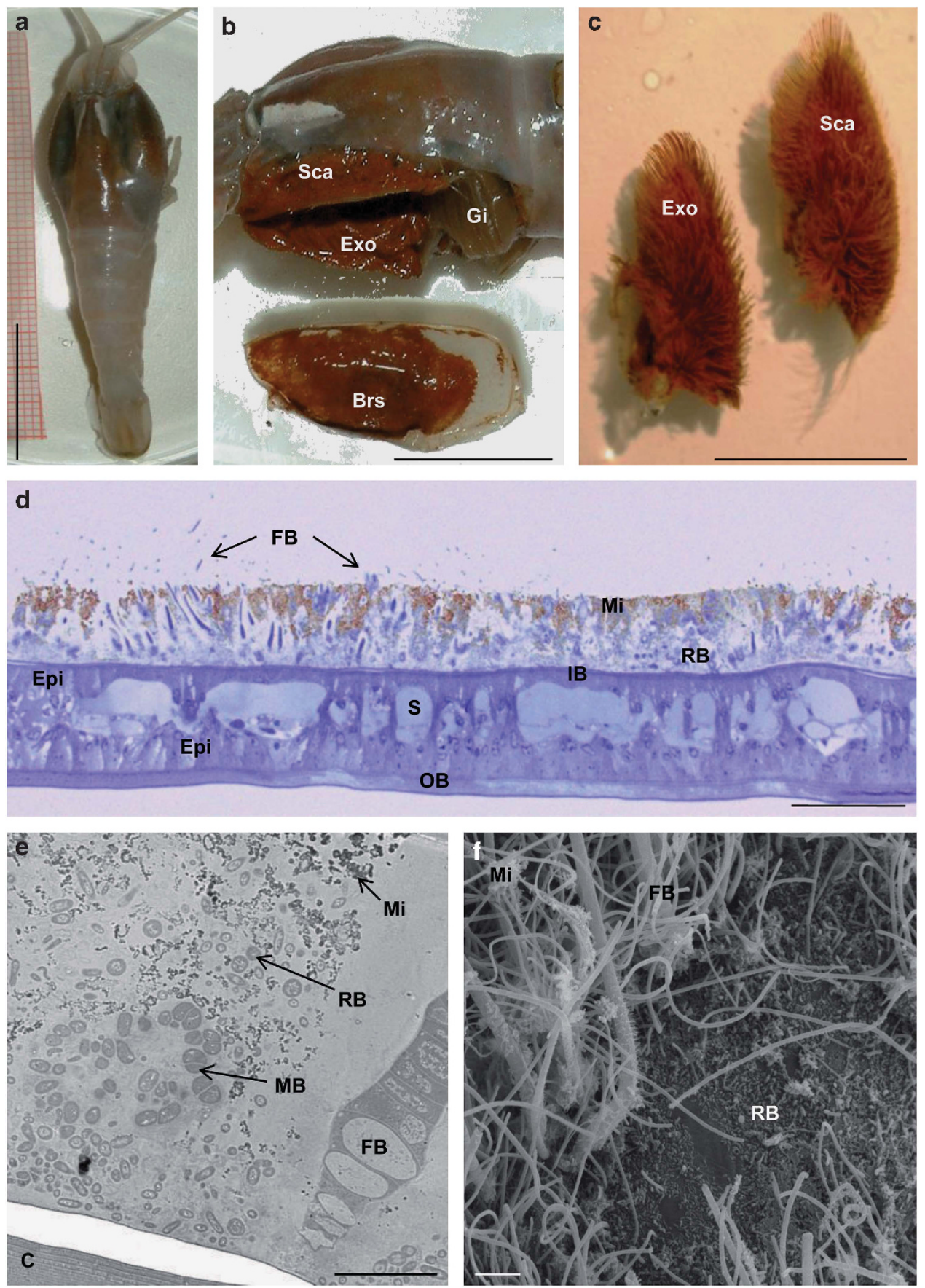

Figure 1 Illustration of the shrimp Rimicaris exoculata gill chamber with the associated bacterial community. (a) Whole shrimp with dilated gill chamber visible on both sides of the cephalothorax. (b) Left gill chamber opened by removal of the branchiostegite (lying below, Brs) and showing the very large mouthparts (scaphognathite, Sca, and exopodite, Exo) as well as the posterior gill set (Gi) -both the mouthparts and the inner side the branchiostegite are colonised by bacterial mats encrusted with particles of red iron oxide. (c) Isolated mouthparts bearing bacteriophore setae sheathed by a thick iron-oxide-encrusted biofilm. (d) Semi-thin cross-section (toluidine blue stained) of the branchiostegite (anterior part), showing the inner and outer integument leaflets (IB and $O B$ ) and the bacterial biofilm growing on the inner side. (e,f) Transmission electron microscopy and scanning electron microscopy images of the branchiostegite biofilm, showing several bacterial morphotypes including rods, nested methanotrophic-like bacteria, thick and thin filaments (pictures taken by Dr L Corbari). Scale bars: (a) $1 \mathrm{~cm}$; (b) and (c) $500 \mathrm{~mm}$; (d) $100 \mu \mathrm{m}$; (e) $5 \mu \mathrm{m}$; (f) $10 \mu \mathrm{m}$. $C$, cuticle; Epi, epidermis; $F B$, filamentous bacteria; $I B$, inner branchiostegite; $M B$, methanotrophic-like bacteria; $M i$, mineral particles; $R B$, rod-shaped bacteria; $S$, blood sinuses. 
(Corbari et al., 2008b), each ecdysis causing shedding of the old cuticle with its bacterial mats. The shrimp R. exoculata, listed as a model organism of an extreme deep-sea environment (CAREX, 2010), is exceptional among crustaceans for its association with bacteria. Recent studies suggest that $R$. exoculata gill chamber epibionts constitute a diversified community with various morphotypes, phylotypes and metabolisms (Zbinden et al., 2004, 2008; Petersen et al., 2009; Hügler et al., 2011; Guri et al., 2012), but no study has directly demonstrated which substrate(s) the bacteria oxidise to fuel their 'chemosynthetic' metabolism(s). This shrimp also harbours a digestive bacterial community (Zbinden and Cambon-Bonavita, 2003; Durand et al., 2010) whose role remains hypothetical (detoxification, nutrition and/or pathogen control).

There is strong evidence, based on stable isotope signatures and essential fatty acid composition, suggesting that the shrimp gets organic matter mainly from its epibionts, rather than from grazing free-living bacteria associated with chimney walls (Gebruk et al., 1993; Pond et al., 1997a, 2000; Rieley et al., 1999; Colaço et al., 2007). Yet this evidence of symbiont-host nutritional relationships is indirect, and how carbon is transferred from bacteria to shrimp remains an open question. The hypothesis of direct transfer of dissolved molecules across the shrimp integument, especially the gill chamber lining, has been proposed on the basis of morphological observations (features dedicated to bacteria farming, absence of scrape marks on the biofilm) (Zbinden et al., 2004; Corbari et al., 2008b), but the nature of the transferred molecules and the integument areas involved remain to be discovered.

The major aims of this study were to test (1) inorganic carbon fixation by active bacterial chemosynthetic metabolisms and (2) the hypothesis of bacterial organic carbon transfer (soluble molecules) to the shrimp tissues. For this, we incubated live shrimps in a pressurised vessel with different isotope-labelled molecules and electron donors, to trace carbon assimilation by the epibionts and shrimp tissues.

\section{Materials and methods}

\section{Shrimp collection}

$R$. exoculata specimens were collected with the slurp-gun operated from the manned submersible Nautile at the Rainbow hydrothermal vent site $\left(36^{\circ} 14^{\prime} \mathrm{N}-33^{\circ} 54^{\prime} \mathrm{W}, 2320 \mathrm{~m}\right.$ depth) during the 'MoMARDREAM-Naut' cruise, July 2007. Healthy specimens were maintained alive in a pressurised IPOCAMP incubator (Shillito et al., 2001) at in-situ pressure $(230$ bars $)$ and temperature $\left(15^{\circ} \mathrm{C}\right)$ for in-vivo experiments (Zbinden et al., 2008). Control specimens were directly frozen at $-80^{\circ} \mathrm{C}$ after collection.

\section{Experiments}

Experiments were carried out only on red-coloured pre-ecdysial specimens (that is, having an established and still-growing bacterial community) (Corbari et al., 2008b). In the IPOCAMP, incubations with isotopic tracers were carried out in flasks filled till to the top with seawater (SW), whose volume (50 or $250 \mathrm{ml}$ ) was chosen according to the treatment duration and number of shrimps to ensure shrimp survival in good physiological condition at the end of the experiment (Shillito et al., 2001; Ravaux et al., 2003). Incorporation of ${ }^{13} \mathrm{C}$ - and ${ }^{14} \mathrm{C}$-bicarbonate by the chemoautotrophic bacteria was tested with different chemical energy sources. ${ }^{14} \mathrm{C}$-acetate and ${ }^{3} \mathrm{H}$-lysine were chosen as representative microbial substrates and/or metabolic by-products liable to mimic transfer of small biomolecules from epibionts to host.

After each experiment, tracer excess was washed off in $0.22-\mu \mathrm{m}$-filtered SW: $15 \mathrm{~min}$ for ${ }^{13} \mathrm{C}$ and 1,5 and $30 \mathrm{~s}, 5$ and $15 \mathrm{~min}$ for the other experiments. The shrimps were then either directly frozen at $-80{ }^{\circ} \mathrm{C}$ or dissected into body parts and tissues of interest: (1) regions colonised by the bacteria: the branchiostegites (integument folds enclosing the gill chamber), later separated into the inner bacterial biofilm $(B B)$ and the outer branchiostegite $(O B)$ or shrimp tissues, and the mouthparts (MP, scaphognathites and exopodites); (2) exchange or absorption organs: gills (Gi), digestive tract $(D T)$ and hepatopancreas (HP); (3) abdominal muscles $(M u)$. In some specimens, the old abdominal cuticle $(A C)$ was separated from the inner tissues (new cuticle and epidermis). In the laboratory, the samples were rinsed once again (see below) and treated to remove unfixed tracers and to preserve the labelled organic molecules before quantification.

${ }^{13} \mathrm{C}$-bicarbonate incorporation. Four and two shrimps were incubated for 4 and $10 \mathrm{~h}$, respectively, in 250-ml flasks containing $1 \mathrm{~g} / \mathrm{L} \mathrm{NaH}{ }^{13} \mathrm{CO}_{3}(98 \%$; Sigma 372382; St Louis, MO, USA) in filtered SW enriched or not (control) with iron $\left(100 \mu \mathrm{M} \mathrm{FeCl}_{2}\right.$; Sigma 372870$)$ or thiosulphate $\left(100 \mu \mathrm{M} \mathrm{Na} \mathrm{Na}_{2} \mathrm{~S}_{2}\right.$; Sigma 72049) as chemical energy source. Before use, the dissected tissue samples were rinsed three times in distilled water before dehydration overnight at $60{ }^{\circ} \mathrm{C}$. Dried samples were finely ground to obtain a powder to vaporise in the mass spectrometer.

${ }^{14} \mathrm{C}$-bicarbonate incorporation. Two specimens were incubated for $6 \mathrm{~h}$ in 50-ml flasks containing $0.25 \mathrm{~g} / \mathrm{L} \mathrm{NaH}^{12} \mathrm{CO}_{3}$ labelled with $80 \mu \mathrm{M} \mathrm{NaH}^{14} \mathrm{CO}_{3}$ ( $4 \mu \mathrm{Ci} / \mathrm{ml}$; GE Healthcare CFA3-5MCI; Buckinghamshire, UK) as inorganic carbon source and dissolved in SW enriched or not with an electron donor $\left(\mathrm{Fe}^{2+}\right.$ or $\mathrm{Na}_{2} \mathrm{~S}_{2} \mathrm{O}_{3}$ ) at the same concentration as above. The first shrimp for each condition was directly frozen at $-80^{\circ} \mathrm{C}$ for autoradiography and scintillation analysis. The second shrimp was dissected into body parts as described above before storage in 
cryotubes at $-80^{\circ} \mathrm{C}$. In unlabelled shrimps (control), the radioactivity level was undetectable to very low in both bacterial mats and shrimp tissues.

In the laboratory, the samples were rinsed four times in distilled water and their fresh weight was determined. After overnight digestion at $50-55{ }^{\circ} \mathrm{C}$ in glass scintillation vials containing $1 \mathrm{ml}$ quaternary ammonium hydroxide $(0.5 \mathrm{~N})$ in toluene (BTS-450 Tissue Solubilizer; Beckman Coulter 580691; Fullerton, CA, USA), they were acidified for $2 \mathrm{~h}$ at room temperature by adding $250 \mu \mathrm{l}$ acetic acid to remove any remaining ${ }^{14} \mathrm{C}$-bicarbonate and the calcium carbonate present in the cuticle or HP. Scintillation liquid (Ready Organic; Beckman Coulter 586600) $(10 \mathrm{ml})$ was added to all samples just before reading.

${ }^{14} \mathrm{C}$-acetate and ${ }^{3} \mathrm{H}$-lysine incorporation. Two sets of three to four shrimps were incubated for $1 \mathrm{~h}$ in $50 \mathrm{ml}$ SW containing either $20 \mu \mathrm{Ci} / \mathrm{ml}{ }^{3} \mathrm{H}$-lysine (GE Healthcare TRK520-1MCI) (that is, $0.2 \mu \mathrm{M}$ ) or $10 \mu \mathrm{Ci} /$ ml sodium ${ }^{14} \mathrm{C}$-acetate (GE Healthcare CFA14-1MCI) (that is, $0.2 \mathrm{~mm}$ ). In both experiments, one entire specimen was immediately frozen after rinsing (for autoradiography and analysis). The others were dissected and the pieces stored at $-80^{\circ} \mathrm{C}$. Samples were treated as in the ${ }^{14} \mathrm{C}$-bicarbonate experiment.

\section{Stable isotope and elemental analysis}

The atomic percentage of stable isotope $\left(\%{ }_{a t}^{13} \mathrm{C}\right)$ of each sample and its carbon content expressed as a percentage of dry weight $\left(\% \mathrm{C}_{\mathrm{dw}}\right)$ were obtained with an isotope ratio spectrometer (Optima, Isoprime, UK) coupled to an elemental analyser (Carlo Erba, Milan, Italy) (Lepoint et al., 2004).

The percentage of natural ${ }^{13} \mathrm{C}$ in control shrimps was first subtracted from the measured ${ }^{13} \mathrm{C}$ percentage in each sample to obtain the percentage of ${ }^{13} \mathrm{C}$ (or total carbon) incorporated during the experiment $\left(\%{ }_{\text {at }}{ }^{13} \mathrm{C}_{\text {inc }}\right)$. Carbon incorporation rates $\left(\mathrm{C}_{\text {inc }}\right)$, expressed in moles of carbon incorporated per time unit and weight unit of total carbon in the sample $\left(\mu \mathrm{molC}_{\text {inc }} \times \mathrm{gC}_{\text {sam }}^{-1} \times \mathrm{h}^{-1}\right)$, were calculated according to the formulas:

$$
\begin{gathered}
\% \text { at }{ }^{13} C_{\mathrm{inc}} \cdot\left(\mathrm{DW}_{\mathrm{sam}} \cdot \% \mathrm{C}_{\mathrm{dw}}\right)=\mathrm{W}^{13} \mathrm{C}_{\mathrm{inc}} \\
\frac{\mathrm{W}^{13} \mathrm{C}_{\mathrm{inc}} / \mathrm{MM}_{\mathrm{C}}}{\left(\mathrm{DW}_{\mathrm{sam}} \cdot \% \mathrm{C}_{\mathrm{dw}}\right) \cdot t}=\mathrm{C}_{\mathrm{inc}}
\end{gathered}
$$

where $\%{ }_{\text {at }}^{13} \mathrm{C}_{\text {inc }}$ is atomic percentage of incorporated ${ }^{13} \mathrm{C}$; $\mathrm{DW}_{\text {sam }}$ is the dry weight of the sample, $\% \mathrm{C}_{\mathrm{dw}}$ is the carbon content expressed as a percentage of dry weight, $\mathrm{DW}_{\mathrm{sam}} . \% \mathrm{C}_{\mathrm{dw}}$ is the weight of carbon in the sample, $\mathrm{W}^{13} \mathrm{C}_{\text {inc }}$ is the weight of ${ }^{13} \mathrm{C}$ incorporated into the sample during the experiment, $\mathrm{MM}_{\mathrm{C}}$ is the molar mass of carbon, $t$ is the duration of the experiment, and $\mathrm{C}_{\mathrm{inc}}$ is the carbon incorporation rate expressed in moles of incorporated carbon per time unit and weight unit of total carbon in the sample.
Measurement of incorporated radioactivity

The beta-radioactivity of the samples was measured for 15 min in liquid phase in a Beckman LS 6500 Scintillation Counter (effective resolution: $0.06 \mathrm{keV}$ ).

Moles of incorporated radioelement are known from the measured number of disintegrations per second (disintegrations per second $\times 2$ half-life in seconds/Avogadro's number). The total incorporation rate, expressed in moles of incorporated molecules per time unit and weight unit of total carbon in the sample $\left(\mu \mathrm{molR}_{\mathrm{inc}} \times \mathrm{gC}_{\mathrm{sam}}^{-1} \times \mathrm{h}^{-1}\right)$, was calculated according to the formula:

$$
\frac{\left({ }^{x} E_{\mathrm{inc}} / f\right)}{\left[\left(\mathrm{FW}_{\mathrm{sam}} \cdot p\right) \cdot \% \mathrm{C}_{\mathrm{dw}}\right] \cdot t}=\mathrm{R}_{\mathrm{inc}}
$$

where ${ }^{\mathrm{x}} E_{\text {inc }}$ is the number of moles of incorporated radioelement, $f$ is the ratio of radioactive to cold molecules in the incubation medium, $\mathrm{FW}_{\text {sam }}$ is the fresh weight of the sample, $p$ is the dry weight/fresh weight ratio measured on control shrimps, $\% \mathrm{C}_{\mathrm{dw}}$ is the carbon content expressed as a percentage of sample dry weight, and $\mathrm{R}_{\text {inc }}$ is the total incorporation rate expressed in moles of incorporated molecules per time unit and weight of total carbon in the sample.

\section{Autoradiography}

Histological localisation of radiotracers was done by autoradiography on frozen shrimps incubated with a radiotracer. To isolate shrimp segments, each frozen shrimp was embedded in Tissue-Tek gel (Sakura 4583; Torrance, CA, USA), directly frozen in liquid nitrogen, and cut into segments $1 \mathrm{~cm}$ long with a hacksaw in a cryostat at $-20^{\circ} \mathrm{C}$. Segments of the cephalothorax (including $M P$ and gills) and the abdomen were directly thawed overnight in fixative solution (2.5\% glutaraldehyde), decalcified in EDTA $(0.2 \mathrm{M}, \mathrm{pH} 8)$, post-fixed in $1 \% \mathrm{OsO}_{4}$ for $2 \mathrm{~h}$, rinsed in distilled water $(4 \times 10 \mathrm{~min})$, dehydrated with ethanol, and embedded in Steedman's wax (polyethylene glycol distearate; Sigma 305413-hexadecanol 9:1; 99\%; Sigma 258741). Twelve-micrometre crosssections were obtained with a microtome (Reichert, Austria) at three levels ( $M P$, gills and abdominal muscles) and deposited on gelatinised glass slides. They were rehydrated, washed in distilled water and then coated with a photographic emulsion film (Hypercoat LM-1; GE Healthcare RPN40) in the dark according to the classical wet method (Ullberg et al., 1982). The slides were developed with KODAK products (KODAK D19-Revelator and KODAK-Fixator; Rochester, NY, USA) after an exposure time of $6-9$ months for ${ }^{14} \mathrm{C}$-bicarbonate or $6 \mathrm{~h}$ to 3 months for ${ }^{14} \mathrm{C}$-acetate and ${ }^{3} \mathrm{H}$-lysine. The slides were mounted in epoxy resin before being observed and photographed with an Olympus AX70 light microscope (Shinjuku, Tokyo, Japan) equipped with a Visicam 5.0 camera (Hilden, Germany). 


\section{Statistical analysis}

All data are reported as mean values \pm s.d. Outliers (possibly due to experimental contamination or to the absence of labelling) were eliminated with Dixon's $Q$ test $(P<0.05)$. One-way analysis of variance (Kruskall-Wallis) was used and all pairwise multiple comparison procedures (Dunn's Method) performed with Sigma Plot 11.0 software (Systat Software Inc., San Jose, CA, USA) were used for sample comparisons. $P<0.05$ was taken as fiducial limit for statistical significance.

Dunn's multiple comparisons vs control group method were used to test the real incorporation of ${ }^{14} \mathrm{C}$.

\section{Results}

${ }^{13} \mathrm{C}$-bicarbonate experiments

The data for ${ }^{13} \mathrm{C}$-bicarbonate incorporation are shown in Figure 2a. Bacterial mats of branchiostegites and $M P$ displayed a high rate of inorganic carbon incorporation from ${ }^{13} \mathrm{C}$-bicarbonate. Other body parts $(O B, D T$ and $M u)$ showed lower rates. All the results appeared to be statistically significant.

After a 10-h incubation, the ${ }^{13} \mathrm{C}$ uptake measured in the bacterial mats was approximately twice as high as after $4 \mathrm{~h}$ (Table 1 ). In the $B B$, it was higher in thiosulphate-incubated shrimps $\left(78.8 \mu \mathrm{molC}_{\mathrm{inc}} \times \mathrm{gC}_{\mathrm{sam}}^{-1}\right)$ than in SW-incubated specimens $\left(52.4 \mu \mathrm{molC}_{\mathrm{inc}} \times \mathrm{gC}_{\mathrm{sam}}^{-1}\right)$.

The incorporation rate was higher in the $M P$ (12.1-16.7 $\mu \mathrm{molC}_{\text {inc }} \times \mathrm{gC}_{\mathrm{sam}}^{-1} \times \mathrm{h}^{-1}$ ) than in the $B B$ (3.9-7.3 $\left.\mathrm{molC}_{\mathrm{inc}} \times \mathrm{gC}_{\mathrm{sam}}^{-1} \times \mathrm{h}^{-1}\right)$. In shrimp tissues, it was higher in the $O B\left(1.1 \mu \mathrm{molC}_{\mathrm{inc}} \times \mathrm{gC}_{\mathrm{sam}}^{-1} \times \mathrm{h}^{-1}\right.$, in the presence of thiosulphate) than in the $D T$ $\left(0.3 \mu \mathrm{molC}_{\text {inc }} \times \mathrm{gC}_{\text {sam }}^{-1} \times \mathrm{h}^{-1}\right)$ or the $\mathrm{Mu}\left(0.2 \mu \mathrm{molC}_{\text {inc }} \times\right.$ $\mathrm{gC}_{\mathrm{sam}}^{-1} \times \mathrm{h}^{-1}$ ). The incorporation rates for $M P$ and $B B$ were significantly different from those of shrimp tissues $(P<0.05)$.

\section{${ }^{14} \mathrm{C}$-bicarbonate experiments}

The radioactivity levels measured in the bacteria and tissues of control shrimps appeared negligible as compared with radiotracer uptake $(P \leqslant 0.001)$ (Figure 2b).

High ${ }^{14} \mathrm{C}$ incorporation rates were observed in the bacterial mats of the $M P$ and $B B$ (Figure 2b), of the same order of magnitude as the corresponding ${ }^{13} \mathrm{C}$ bicarbonate incorporation rates. The rate was much higher in the presence of iron or thiosulphate. In the $M P$ and $B B$, respectively, it reached 10.4 and $5.4 \mu \mathrm{molC}_{\text {inc }} \times \mathrm{gC}_{\mathrm{sam}}^{-1} \times \mathrm{h}^{-1}$ in the presence of thiosulphate and only 3.9 and $2.8 \mu$ molC $_{\text {inc }} \times \mathrm{gC}_{\text {sam }}^{-1} \times \mathrm{h}^{-1}$ for shrimps incubated in SW alone.

Most of the shrimp tissues analysed showed significant ${ }^{14} \mathrm{C}$ incorporation, whatever the incubation conditions (Figure 2b). The highest carbon incorporation rates were recorded in the tegumental tissues of the gill chambers, that is, the $O B\left(2.7 \mu\right.$ molC $_{\text {inc }} \times$ $\left.\mathrm{gC}_{\text {sam }}^{-1} \times \mathrm{h}^{-1}\right)$ and the $G i\left(0.2 \mu \mathrm{molC}_{\text {inc }} \times \mathrm{gC}_{\text {sam }}^{-1} \times \mathrm{h}^{-1}\right)$. The rates recorded for the internal tissues of all shrimps (Mu: 0.01; DT: 0.04; HP: $0.01 \mu$ molC $_{\text {inc }} \times$ $\mathrm{gC}_{\text {sam }}^{-1} \times \mathrm{h}^{-1}$ ) were low to very low, but nevertheless significant $(P \leqslant 0.001)$, the digestive gland displaying the lowest values. The $A C$ showed a surprisingly high incorporation rate $\left(0.6 \mu\right.$ molC $_{\text {inc }} \times \mathrm{gC}_{\mathrm{sam}}^{-1} \times \mathrm{h}^{-1}$ in the presence of iron), to be explained below.

\section{${ }^{14} \mathrm{C}$-acetate experiments}

The results for ${ }^{14} \mathrm{C}$ incorporation from acetate are shown in Figure 3a. Bacterial mats ( $M P$ and $B B$ ) showed high rates, indicating that acetate is a suitable carbon source for these bacteria. The rate recorded in $\mathrm{SW}\left(61.3 \mu \mathrm{molAc}_{\mathrm{inc}} \times \mathrm{gC}_{\mathrm{sam}}^{-1} \times \mathrm{h}^{-1}\right)$ was 15 times the rate of carbon incorporation from ${ }^{14} \mathrm{C}$ bicarbonate $\left(3.9 \mu \mathrm{molC}_{\text {inc }} \times \mathrm{gC}_{\mathrm{sam}}^{-1} \times \mathrm{h}^{-1}\right.$ in $\left.M P\right)$.

High rates of ${ }^{14} \mathrm{C}$ incorporation were measured in the integument, especially in areas lining the gill
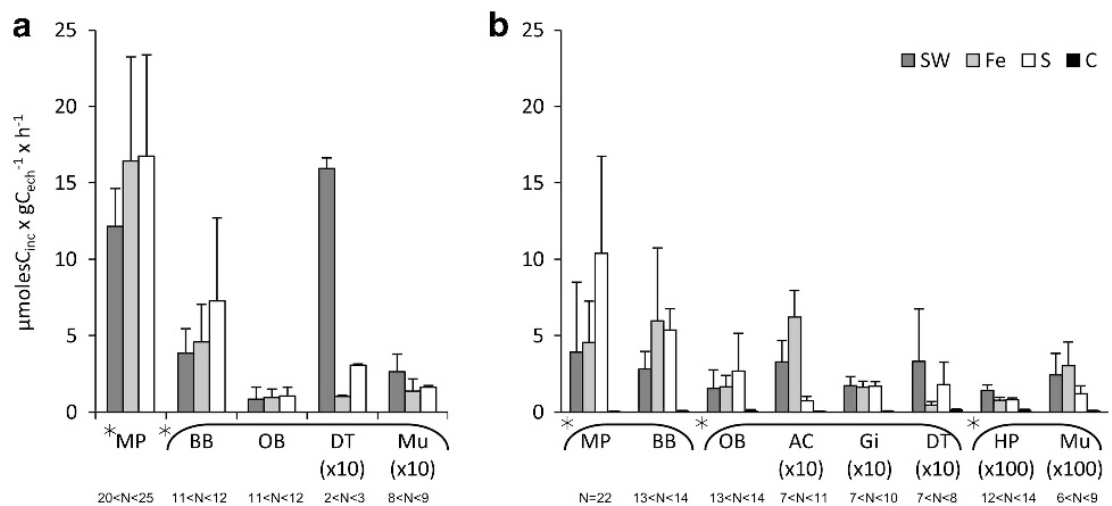

Figure 2 Rates of inorganic carbon incorporation into the bacterial mats of the mouthparts and branchiostegite and into shrimp tissues, as calculated from ${ }^{13} \mathrm{C}$ fixation (a) or ${ }^{14} \mathrm{C}$ fixation (b) data. The shrimps were incubated: (a) for 4 or $10 \mathrm{~h}$ in $\mathrm{NaH}^{13} \mathrm{CO}_{3}$ in pure seawater

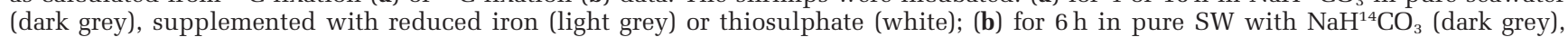
supplemented with iron (light grey) or thiosulphate (white). The radioactivity measured in control shrimp tissues is shown (black) for comparison. Stars indicate significant differences between groups of tissues; $(\times 10, \times 100)$ indicates tissues for which the values were multiplied by 10 or 100 for graph presentation; ' $N$ ' indicates the number of samples for each data bar. 
Table 1 Total amounts of inorganic carbon $\left(\mu \mathrm{molC}_{\mathrm{inc}} \times \mathrm{gC}_{\mathrm{sam}}^{-1} \pm\right.$ s.d. $)$ incorporated after 4 and $10 \mathrm{~h}$ into the body parts of shrimps incubated with ${ }^{13} \mathrm{C}$-bicarbonate in the presence of seawater, or seawater supplemented with iron or thiosulphate

\begin{tabular}{|c|c|c|}
\hline & \multicolumn{2}{|c|}{$\begin{array}{l}\text { Incorporated inorganic }{ }^{13} \mathrm{C} \text { per } g \text { of organic } C \text { in the } \\
\text { sample }\left(\mu \mathrm{mol} C_{\text {inc }} \times \mathrm{gC}_{\text {sam }}^{-1}\right) \text { after } 4 \text { and } 10 \mathrm{~h} \text { incubations } \\
\text { with } \mathrm{NaH}^{13} \mathrm{CO}_{3} \text { in } \mathrm{SW}, \mathrm{SW}+\mathrm{Fe} \text { and } \mathrm{SW}+\mathrm{S}\end{array}$} \\
\hline & $\mathrm{NaH}^{13} \mathrm{CO}_{3}-4 \mathrm{~h}$ & $\mathrm{NaH}^{13} \mathrm{CO}_{3}-10 \mathrm{~h}$ \\
\hline \multicolumn{3}{|c|}{ Shrimp tissues } \\
\hline MP & $50.4 \pm 10.3$ & $103.0 \pm 8.2$ \\
\hline $\mathrm{BB}$ & $13.3 \pm 6.3$ & $52.4 \pm 3.4$ \\
\hline OB & $4.3 \pm 3.3$ & $3.1 \pm 0.5$ \\
\hline DT & I & $15.9 \pm 0.7$ \\
\hline $\mathrm{Mu}$ & $1.1 \pm 0.6$ & $2.6 \pm 0.0$ \\
\hline \multicolumn{3}{|l|}{$\mathrm{Fe}$} \\
\hline MP & $65.7 \pm 27.3$ & / \\
\hline BB & $22.8 \pm 9.8$ & $24.0 \pm 2.1$ \\
\hline OB & $4.8 \pm 3.5$ & $8.4 \pm 0.3$ \\
\hline DT & / & $1.3 \pm 0.5$ \\
\hline $\mathrm{Mu}$ & $0.8 \pm 0.1$ & $0.5 \pm 0.0$ \\
\hline \multicolumn{3}{|l|}{$S$} \\
\hline MP & $67.9 \pm 29.9$ & $158.5 \pm 7.0$ \\
\hline BB & $28.4 \pm 25.0$ & $78.8 \pm 3.7$ \\
\hline OB & $5.0 \pm 2.1$ & $4.8 \pm 0.4$ \\
\hline DT & I & $3.1 \pm 0.1$ \\
\hline $\mathrm{Mu}$ & $0.6 \pm 0.0$ & $1.7 \pm 0.14$ \\
\hline
\end{tabular}

Abbreviations: $\mathrm{BB}$, branchiostegite biofilm; DT, digestive tract; $\mathrm{Fe}$, iron condition; MP, mouthparts; $\mathrm{Mu}$, muscles; OB, outer branchiostegite; S, thiosulphate condition; SW, seawater.

chamber, that is, $O B$ and $G i\left(7.9\right.$ and $7.3 \mu \operatorname{molAc}_{\text {inc }} \times$ $\mathrm{gC}_{\text {sam }}^{-1} \times \mathrm{h}^{-1}$, respectively). The level remained low but measurable in the internal tissues. In the $M u$ and $H P$, the rate did not exceed $0.1 \mu$ molAc $_{\text {inc }} \times$ $\mathrm{gC}_{\text {sam }}^{-1} \times \mathrm{h}^{-1}$. It was slightly higher in the $D T$ $\left(0.4 \mu \mathrm{molAc}_{\text {inc }} \times \mathrm{gC}_{\mathrm{sam}}^{-1} \times \mathrm{h}^{-1}\right)$. In the $A C$, a distinction was made between the old, outer cuticle $\left(A C_{o}\right)$ and the inner tissues $\left(A C_{n}\right)$. The ${ }^{14} \mathrm{C}$ incorporation rate for the whole $A C$ was mainly due to high ${ }^{14} \mathrm{C}$ uptake into the inner, living tissues $\left(A C_{n}, 4.8 \mu \mathrm{molAc}_{\mathrm{inc}} \times\right.$ $\mathrm{gC}_{\mathrm{sam}}^{-1} \times \mathrm{h}^{-1}$ ), that is, the epidermis secreting the new cuticle, while the inert old cuticle showed low labelling $\left(A C_{o}, 0.7 \mu \mathrm{molAc}_{\text {inc }} \times \mathrm{gC}_{\text {sam }}^{-1} \times \mathrm{h}^{-1}\right)$.

\section{${ }^{3} \mathrm{H}$-lysine experiments}

${ }^{3} \mathrm{H}$-lysine incorporation rates were about 100 times lower than the ${ }^{14} \mathrm{C}$-acetate incorporation rates $\left(0.7 \mu\right.$ molLys $_{\text {inc }} \times \mathrm{gC}_{\text {sam }}^{-1} \times \mathrm{h}^{-1} \quad$ vs $\quad 61.7 \mu \mathrm{molAc}_{\text {inc }} \times$ $\mathrm{gC}_{\text {sam }}^{-1} \times \mathrm{h}^{-1}$ in the $B B$ ) (Figure $3 \mathrm{~b}$ ). The highest rates were again found in the bacterial mats $(M P$ and $B B)$, suggesting that these bacteria can use lysine, probably for protein synthesis. Significant rates were measured in the gill chamber integument $(O B$ and $G i)$ (34.1 and 16.1 nmolLys $_{\text {inc }} \times \mathrm{gC}_{\text {sam }}^{-1} \times \mathrm{h}^{-1}$, respectively), while the internal tissues (except the $M u: 0.8$ nmolLys $_{\text {inc }} \times \mathrm{gC}_{\text {sam }}^{-1} \times \mathrm{h}^{-1}$ ) showed low labelling.

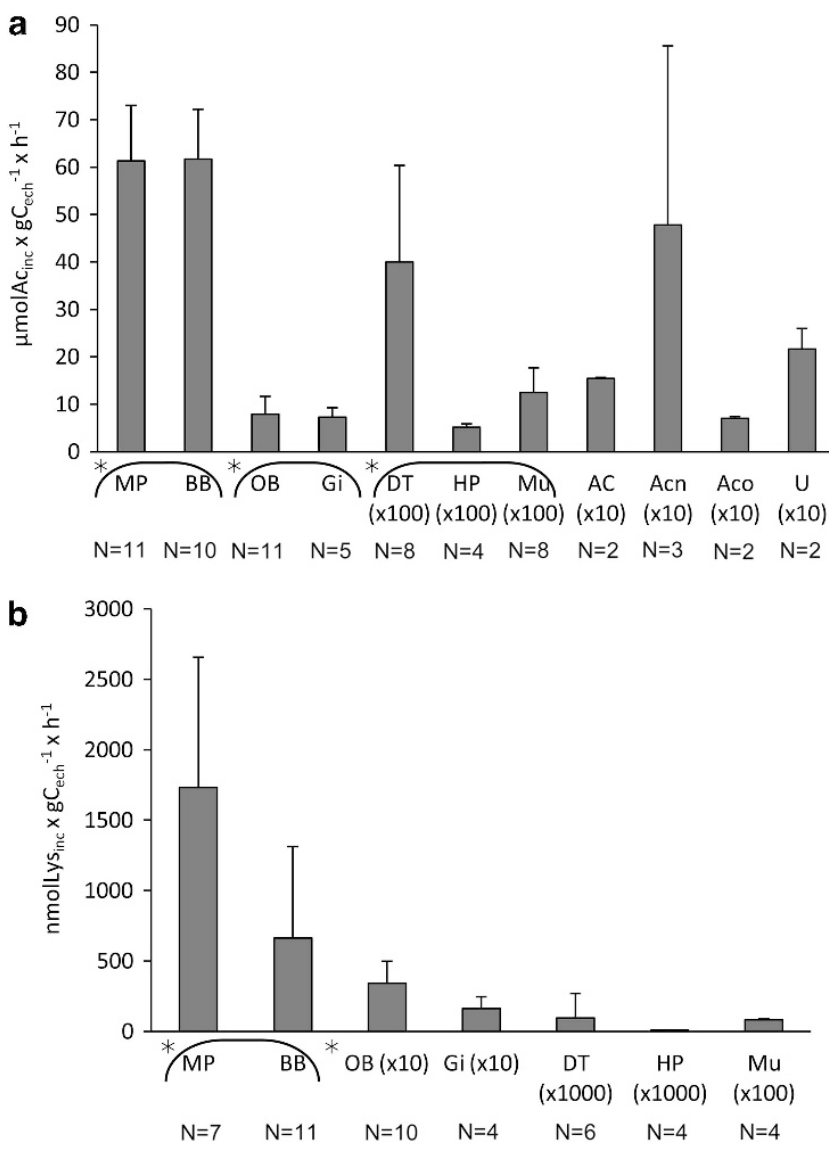

Figure 3 Rates of incorporation of ${ }^{14} \mathrm{C}$ (a) and ${ }^{3} \mathrm{H}$ (b) into the bacterial mats and inner tissues of $R$. exoculata shrimps incubated for $1 \mathrm{~h}$ with ${ }^{14} \mathrm{C}$-acetate or ${ }^{3} \mathrm{H}$-lysine in pure SW. Stars indicate significantly different groups of tissues; $(\times 10, \times 100$, $\times 1000$ ) indicates tissues for which the values were multiplied by 10,100 or 1000 for graph presentation; ' $N$ ' indicates the number of samples for each data bar. $U$, uropods.

\section{Autoradiography}

Our autoradiographic observations were in good agreement with the analytical data, confirming the distribution of the radiolabelled molecules among the bacterial mats and shrimp tissues (see Supplementary Information 2-Figures 7a and $\mathrm{b}$ for negative controls).

In the bacterial mats associated with the $M P$ and branchiostegites, results for the three radiotracer incubations were quite similar. The labelling intensity depended on the specific radioactivity of the isotope, the exposure time and the amount of radiotracer incorporated. ${ }^{3} \mathrm{H}$-lysine gave the best result with the shortest exposure time, followed by ${ }^{14} \mathrm{C}$-acetate and ${ }^{14} \mathrm{C}$-bicarbonate. Silver grain precipitation (in the photographic emulsion) always appeared first along the bacterial filaments (Figures 4a and c), eventually covering the whole length of the filaments as a dense black deposit (Figures 4b and d). By comparing the pictures obtained after short and long exposure times we were able to distinguish the labelled filamentous bacteria from the mineral crust of iron oxides: the 


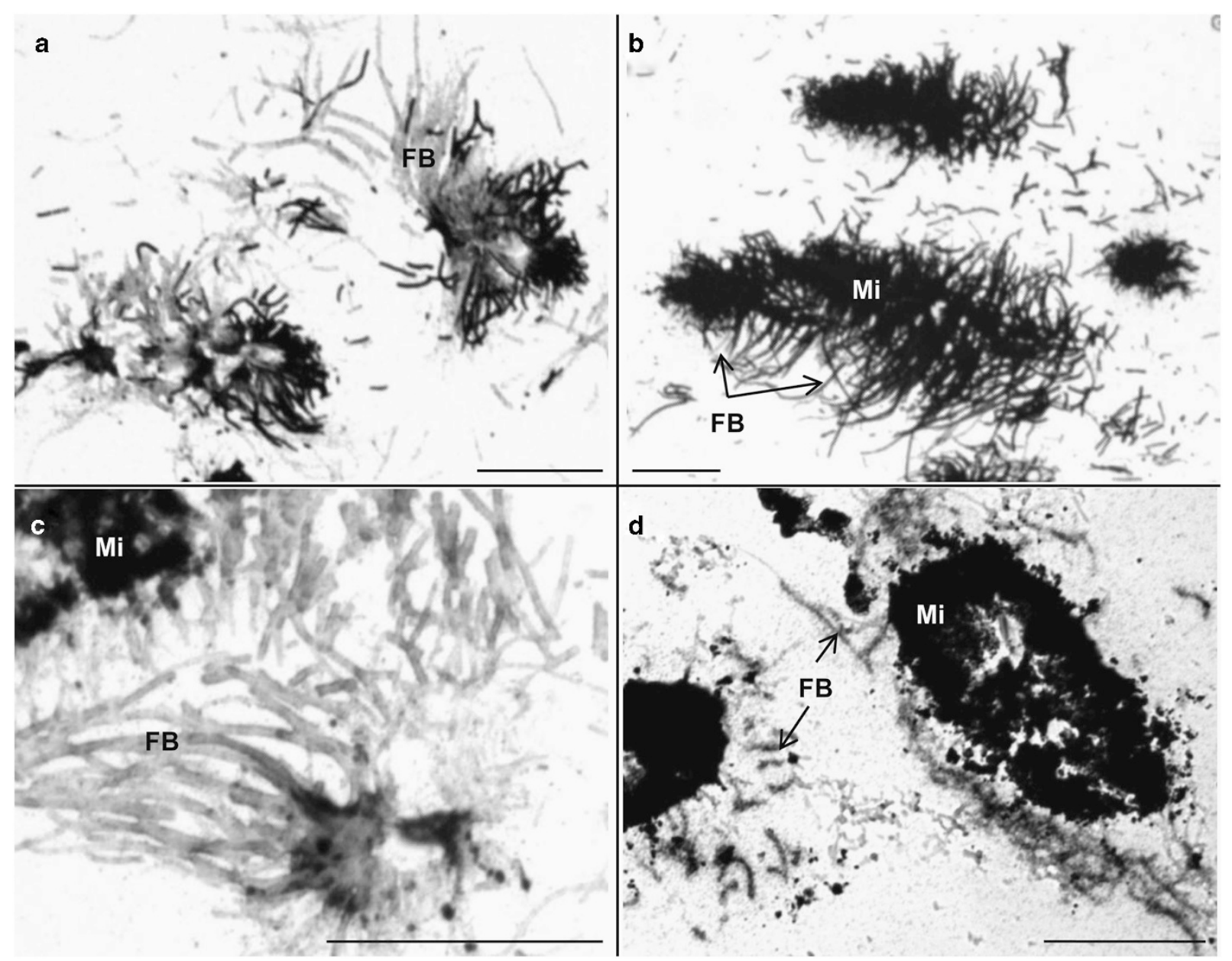

Figure 4 Autoradiographs of histological sections: cross-sectioned bacteriophore setae of the mouthparts of $R$. exoculata shrimps incubated for $1 \mathrm{~h}$ with ${ }^{3} \mathrm{H}$-lysine $(\mathbf{a}, \mathbf{b})$ or for $6 \mathrm{~h}$ with ${ }^{14} \mathrm{C}$-bicarbonate $(\mathbf{c}, \mathbf{d})$. (a) Filamentous bacteria are distinguished from mineral deposits and labelled on short segments only. (b) The filamentous bacteria are labelled over their entire length. (c) Filamentous bacteria are poorly or not labelled. (d) Discontinuous labelling appears on the distal part of the filamentous bacteria but does not stain them close to the setae. Exposure times: (a) 12 h, (b) 11 days, (c) 10 weeks and (d) 34 weeks. Scale bars: $100 \mu \mathrm{m}$. FB, filamentous bacteria; Mi, mineral.

latter also appeared as dark masses, but they were not labelled, whereas the bacteria located inside or below the mineral crust were moderately labelled (Figure 5a).

The shrimp tegumental tissues appeared densely labelled after incubation with ${ }^{3} \mathrm{H}$-lysine or ${ }^{14} \mathrm{C}$ acetate, but sections of shrimps incubated with ${ }^{14} \mathrm{C}$-bicarbonate required very long exposure times before the label appeared. After 20-30 days of exposure, gills and muscles also appeared moderately labelled (Figures $5 \mathrm{~b}$ and $\mathrm{c}$ ), but neither the $D T$ nor the $H P$ showed any measurable labelling. Detailed views of the branchiostegite (Figure 5a) confirmed and explained the analytical data obtained for the abdominal integument: living tissues synthesising new cuticle and the new cuticle itself showed the most intense labelling. In contrast, the overlying old cuticle remained free of silver grains except in its lower part, which was probably infused with moulting fluid enzymes secreted by the epidermis (Compère et al., 2004).

\section{Discussion}

The in-vivo experiments presented here provide direct evidence that $R$. exoculata epibionts are autotrophic. These are the first experiments to have been carried out on live shrimps together with their epibionts, and the first to demonstrate a mutualistic relationship in this bacteria-shrimp symbiosis under in-situ pressure conditions.

\section{Carbon fixation by bacterial chemosynthesis}

Once thought to be a monoculture of a single, pleomorphic phylotype of epsilonproteobacteria, the gill chamber epibiont population of $R$. exoculata is now regarded as a functional consortium or syntrophic community (Stams and Plugge, 2009) dominated by gamma- and epsilonproteobacteria. By combining 16S rRNA and functional gene analysis with in-situ hybridisation and transmission electron microscopy observations on $R$. exoculata 

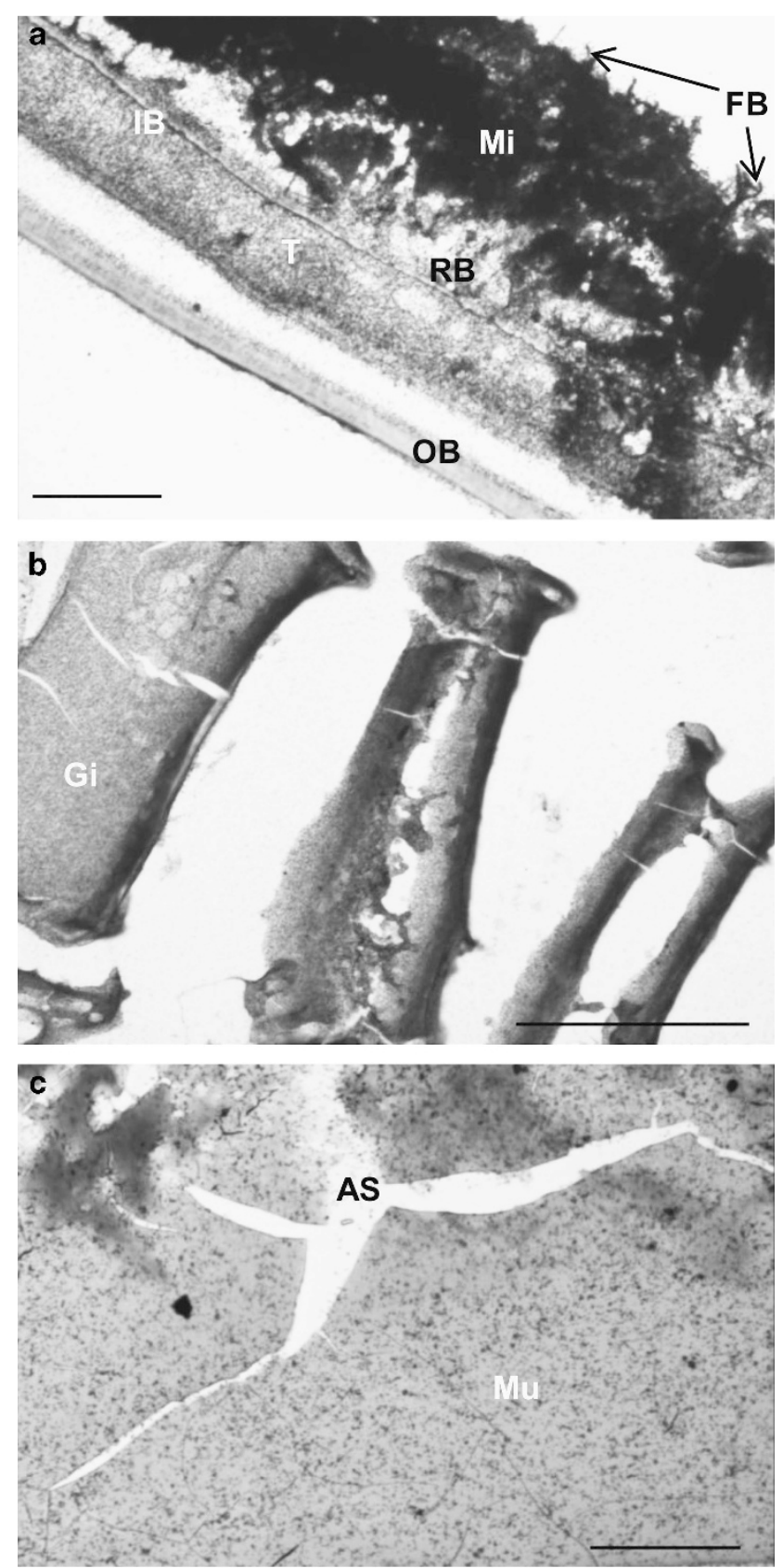

Figure 5 Autoradiographs of different cross-sectioned body parts of $R$. exoculata shrimps incubated for $1 \mathrm{~h}$ with ${ }^{14} \mathrm{C}$-acetate (a, c) or ${ }^{3} \mathrm{H}$-lysine (b): (a) branchiostegite (3-day exposure) showing intense labelling of emerging filamentous bacteria and much weaker labelling below the mineral crust, a dense silver deposit covering the living tissue, that is, both the inner and the outer epidermis and their respective new cuticles, while the old outer cuticle remains almost free of silver particles; (b) gills (20-days exposure); (c) abdominal muscles (29-days exposure) labelled moderately but more intensely than the background. Scale bar: $100 \mu \mathrm{m}$. $A S$, sectioning artificial space; $F B$, filamentous bacteria; $M i$, mineral crust; $M u$, muscles; $O B$, outer branchiostegite (old cuticle separated from the new one); $R B$, rod-shaped bacteria; $T$, tissues including the epidermis bordered by the new cuticle being deposited.

epibionts and their free-living or symbiotic relatives from vent habitats, investigators (Campbell et al., 2006; Zbinden et al., 2008; Petersen et al., 2009;
Goffredi, 2010; Hügler et al., 2010, 2011; Guri et al., 2012) have evidenced epsilonproteobacteria of Marine Groups 1 (the new family Thiovulgaceae) and 2 , as thick ( $3-\mu \mathrm{m}$ wide) and thin $(1-\mu \mathrm{m}$ wide) filaments, respectively. Both should oxidise sulphur compounds through the Sox pathway and fix carbon through the reverse tricarboxylic acid cycle (SoxB and aclA gene sequences). Authors have also identified gamma-proteobacterial epibionts of the Thiotrichaceae family (Leucothrix group), together with some free-living members and some other invertebrate ectosymbionts, mainly of crustaceans (Goffredi, 2010). These gammaproteobacteria appearing at least as filamentous and rod-shaped morphotypes can probably grow as sulphide oxidisers, most likely using the APS pathway for energy generation and the Calvin-Benson-Bassham cycle for carbon fixation (aprA and $c b b \mathrm{M}$ gene sequences, respectively) (Zbinden et al., 2008; Hügler et al., 2010, 2011; Guri et al., 2012). In addition, coccoidshaped cells with intracytoplasmic membrane stacks have been identified as type-I methanotrophic gammaproteobacteria (pmoA gene sequence) (Corbari et al., 2008a; Zbinden et al., 2008; Guri et al., 2012), and deltaproteobacteria related to Desulfocapsa have been identified thanks to their aprA and hydrogenase gene sequences (Hügler et al., 2011), suggesting they can grow lithotrophically using hydrogen as electron donor for sulphate reduction. On this basis, the authors hypothesise that an internal sulphur cycle between sulphur-oxidising epsilon- and gammaproteobacteria and sulphate-reducing deltaproteobacteria could take place in the shrimp gill chamber, as proposed for oligochete symbiosis (Dubilier et al., 2001).

The following results of the present study support the view that shrimp-associated bacteria carry out chemosynthetic inorganic carbon fixation: (1) the carbon incorporation rates for ${ }^{13} \mathrm{C}$ - and ${ }^{14} \mathrm{C}$-bicarbonate are in good agreement, (2) they increase in the presence of electron donors $\left(\mathrm{S}_{2} \mathrm{O}_{3}^{2-}, \mathrm{Fe}^{2+}\right)$, (3) they are stable over time, as confirmed by the timerelated increase in ${ }^{13} \mathrm{C}$ incorporation and (4) autoradiographs of histological sections show labelling of bacterial mats.

The carbon fixation rates observed here are similar to but somewhat higher than those observed by Polz et al. (1998): 3.9 vs $2 \mu \mathrm{molC}_{\text {inc }} \times \mathrm{gC}_{\text {sam }}^{-1} \times \mathrm{h}^{-1}$ for the $M P$ of shrimp incubated in SW. This comparison is somewhat uncertain, as we had to convert Polz's data, expressed per weight unit of protein, into values given per weight unit of total carbon, the carbon content of proteins being estimated at $45 \%$ (Rouwenhorst et al., 1991). Yet, the consistently higher rates found here might be due to the incubation of live shrimps under in-situ pressure (230 bars in this study), as opposed to the use, in previous experiments, of pieces of dead shrimp under atmospheric pressure. Active chemoautotrophy might be promoted by preserving shrimps and 
bacteria in good physiological condition (Ravaux et al., 2003). Accordingly, Zbinden et al. (2008) observed $<30 \%$ degraded epibionts in re-pressurised shrimps. The carbon fixation rates determined here are much lower, however, than those obtained for other chemosynthetic symbionts (bacterial homogenates or endobacteria of bivalve gills), for example, those of Bathymodiolus thermophilus: $150 \mu \mathrm{molC}_{\mathrm{inc}} \times \mathrm{gC}_{\mathrm{sam}}^{-1} \times \mathrm{h}^{-1}$ in SW (Nelson et al., 1995), or Solemya velum: $2500 \mu \mathrm{molC}_{\text {inc }} \times \mathrm{gC}_{\text {sam }}^{-1} \times$ $\mathrm{h}^{-1}$ in the presence of thiosulphate (Scott and Cavanaugh, 2007). Moreover, owing to the relatively low energy level of thiosulphate as compared with sulphide, the latter authors observed threefold higher carbon fixation rates with $0.2 \mathrm{mM} \mathrm{Na}_{2} \mathrm{~S}$ $\left(70 \mu \mathrm{molC} \times \mathrm{g}_{\text {prot }}^{-1} \times \mathrm{min}^{-1}\right)$ than with $1 \mathrm{mM} \mathrm{Na}_{2} \mathrm{~S}_{2} \mathrm{O}_{3}$ $\left(20 \mu \mathrm{molC} \times \mathrm{g}_{\text {prot }}^{-1} \times \mathrm{min}^{-1}\right)$.

That the presence of an electron donor increases the carbon fixation rate indicates that $\mathrm{Na}_{2} \mathrm{~S}_{2} \mathrm{O}_{3}$, and $\mathrm{Fe}^{2+}$ at least contribute to fuelling $R$. exoculata epibionts, and our autoradiography data suggest that chemosynthesis occurs at least in the large filamentous bacteria (epsilonproteobacteria of Marine Group 1), which appeared more intensely labelled than the thin filamentous and rod-shaped ones (epsilonproteobacteria of Marine Group 2 and gammaproteobacteria). The view that $R$. exoculata epibionts have sulphide-oxidising activity is consistent, moreover, with the fact epsilon- and gammaproteobacteria are assumed to have such activity, on the basis of the group affiliation of the former (Petersen et al., 2009; Goffredi, 2010; Guri et al., 2012) and because the latter possess functional SoxB and aprA genes (Hügler et al., 2010, 2011). We cannot say, however, what the epibiotic bacteria of $R$. exoculata use as predominant energy source. Methane and hydrogen, found in hydrothermal fluids from the Rainbow vent field along with sulphide and iron (Charlou et al., 2002; Douville et al., 2002; Schmidt et al., 2008), are also potential drivers of chemoautotrophy. In particular, the type-I methanotrophic gammaproteobacteria may use methane as both electron and carbon source (Zbinden et al., 2008; Guri et al., 2012), deltaproteobacteria are believed to use $\mathrm{H}_{2}$ for sulphate reduction (Hügler et al., 2011), and epsilonproteobacteria (of Marine Groups I and II) may use $\mathrm{H}_{2}$ instead of sulphide for chemosynthesis, as proposed for Bathymodiolus gill endosymbionts (Petersen et al., 2011). The possibility that $R$. exoculata epibionts might use $\mathrm{H}_{2}$ is strongly supported by the identification of a hupL gene sequence from Group-2 epsilonproteobacteria (Hügler et al., 2011) among the $R$. exoculata epibionts and by the metabolic capabilities reported for Campylobacterales, especially of the family Thiovulgaceae (Campbell et al., 2006; Goffredi, 2010). We have also tested methane and hydrogen (see Supplementary Information 1), but we observed rapid death of the incubated shrimps, so they were discarded. Furthermore, whether $\mathrm{CH}_{4}$ or $\mathrm{H}_{2}$-metabolic genes are actively expressed or not has not been determined. Biotic iron oxidation by $R$. exoculata epibionts has been proposed (Zbinden et al., 2004, 2008; Corbari et al., 2008a) on the basis of the close association of these bacteria with heavy iron-oxyhydroxide deposits. Our results support this hypothesis, but evidence is lacking as to the ability of the bacterial phylotypes identified so far to oxidise iron. Furthermore, abiotic iron-oxide precipitation can compete strongly with biotic iron oxidation (Schmidt et al., 2009), bacterial cell walls can induce it (Corbari et al., 2008a).

We also show here that $R$. exoculata epibionts can incorporate ${ }^{14} \mathrm{C}$-acetate and ${ }^{3} \mathrm{H}$-lysine much faster than they incorporate ${ }^{14} \mathrm{C}$ from bicarbonate. In the branchiostegite bacterial mats, the rate of organic carbon incorporation from acetate $\left(61.7 \mu \mathrm{molAc}_{\mathrm{inc}} \times\right.$ $\mathrm{gC}_{\mathrm{sam}}^{-1} \times \mathrm{h}^{-1}$ ) was 10-20 times the rate observed with ${ }^{14} \mathrm{C}$-bicarbonate, depending on whether thiosulphate was present $\left(5.4 \mu \mathrm{molC}_{\mathrm{inc}} \times \mathrm{gC}_{\mathrm{sam}}^{-1} \times \mathrm{h}^{-1}\right)$ or not $\left(2.8 \mu \mathrm{molC}_{\text {inc }} \times \mathrm{gC}_{\text {sam }}^{-1} \times \mathrm{h}^{-1}\right)$. This may be due to the presence of heterotrophic bacteria, but to date, this has not been investigated. Our observation that the thick bacterial filaments were intensely labelled with all three radiotracers, and that the thin ones were also labelled to a lesser extent, suggests that at least the epsilonproteobacteria might switch to a mixotrophic metabolism and use small organic molecules, when available, as energy and/or carbon sources. Acetate and amino-acid assimilation is thus unsurprising and might reflect a capacity of certain chemolithoautotrophic bacterial epibionts to adjust their metabolism to changes in their geochemical environment. A versatile (autotrophic/mixotrophic/ heterotrophic) energy metabolism using several electron donors (including hydrogen and organic compounds) and acceptors (including oxygen and nitrate) has indeed been reported for free and symbiotic epsilonproteobacteria of the Thiovulgaceae family (Campbell et al., 2006; Goffredi, 2010) and suggested for $R$. exoculata ectosymbionts (Hügler et al., 2011). Mixotrophy/heterotrophy is also commonly accepted as a possible feature of gammaproteobacteria of the Thiotrichaceae family (Goffredi, 2010), as most Beggiatoa species can grow on acetate as sole added carbon source (Larkin and Strohl, 1983). It has been proposed but not investigated for R. exoculata epibionts (Hügler et al., 2011). In support of this hypothesis, a metagenomic study has revealed in Riftia pachyptila endosymbionts the presence of all genes required for heterotrophic metabolism (Robidart et al., 2008), and a metaproteomic study has pinpointed acetate as a substrate for bacterial endosymbionts of the gutless marine worm Olavius algarvensis (Kleiner et al., 2012). Schulz and Jørgensen (2001) interpret the metabolic flexibility of filamentous sulphur-oxidising bacteria, especially those of the Thiothrix group, and their ability to grow heterotrophically or autotrophically on different sulphur species, as a need to overcome disadvantages of their sessile life and to adapt their activity to changes in substrate availability (oxygen, 
sulphide). In $R$. exoculata, the obvious variability of bacterial assemblages according to the gill chamber area, the individual and the vent site (Zbinden et al., 2008; Petersen et al., 2009; Hügler et al., 2011) suggests a consortium composition plasticity as a response to varying vent fluid composition (Charlou et al., 2002; Schmidt et al., 2008) and to fluctuating geochemical or micro-environmental conditions in the zone of mixing with deep water.

The relatively high carbon fixation rate observed in SW alone suggests that $R$. exoculata epibionts have an internal energy store that supplies autotrophic metabolisms in the absence of an external electron donor, for example, when the shrimps swim from reduced-compound-rich hydrothermal fluid to oxic (reduced-compound-poor) deep water. Such carbon fixation has previously been evidenced in Bathymodiolus thermophilius and $R$. exoculata symbionts (Nelson et al., 1995; Polz et al., 1998). Energy could be stored as iron polyphosphate and sulphur globules like those observed ultrastructurally by Wirsen et al. (1993) and Zbinden et al. (2008) in thin filamentous bacteria. These could be identified as Leucothrix-like gamma-ectosymbionts because their APS pathway allows production of intermediate sulphur compounds and because the storage role of similar globules is well documented in their shallow-water relatives (Larkin and Strohl, 1983; Schulz and Jørgensen, 2001). Furthermore, these globules were shown to be empty in specimens maintained in a pressurised aquarium without electron donors (Zbinden et al., 2008). This suggests that the enhanced carbon fixation observed in the presence of thiosulphate as compared with pure SW might reflect a switch of gamma- and/or epsilonepibionts to an external energy source supporting autotrophic metabolism.

\section{Bacteria-host transfers}

Several authors propose that organic nutrients might be transferred from epibionts to $R$. exoculata (Casanova et al., 1993; Zbinden et al., 2004; Corbari et al., 2008b). Others, arguing that the cuticle is impermeable, reject this hypothesis (Segonzac et al., 1993; Gebruk et al., 2000). The latter authors refer to an experiment (Anderson and Stephens, 1969) or to subsequent review papers (Stephens, 1988; Preston, 1993; Gebruk et al., 2000) suggesting that crustaceans, in contrast to many other marine invertebrates, cannot take up dissolved organic matter or dissolved organic carbon. According to Anderson and Stephens (1969), the apparent incorporation of radiotracers by crustaceans was due to uptake by epibionts alone and not by the crustaceans themselves. Yet these authors worked with whole organisms, and never separated the internal tissues from the integument and the epibionts as we have done here.

The present results demonstrate the transfer of carbon fixed by bacteria to the host shrimp tissues and the ability of shrimps to take up dissolved organic molecules such as acetate or lysine across their integument. Together with our autoradiographs, the higher radiotracer concentrations in the shrimp tissues than in the incubation media (Table 2) and the incorporation of ${ }^{3} \mathrm{H}$-lysine and ${ }^{14} \mathrm{C}$-acetate into the $M u$ (proteins) and the $H P$ (storage lipids) confirm their active uptake and their accumulation in shrimp insoluble organic matter. Our separate analysis of the old and new cuticles of the abdominal integument and the corresponding autoradiographs also suggest that the new cuticle and the secreting epithelium incorporate more labelled molecules, probably because of the intense biosynthetic activity at this level in pre-ecdysial crustaceans.

These results thus constitute in-vivo experimental evidence of nutritional transfer of bacteria-fixed

Table 2 Initial and final concentrations (in $\mu \mathrm{M}$ ) of labelled compounds $\left({ }^{13} \mathrm{C},{ }^{14} \mathrm{C}\right.$-bicarbonate, ${ }^{14} \mathrm{C}$-acetate, ${ }^{3} \mathrm{H}$-lysine) in the incubation media and the shrimp body parts

\begin{tabular}{|c|c|c|c|}
\hline \multirow{2}{*}{$\begin{array}{l}\text { Labelled } \\
\text { compounds in } \\
\text { each incubation } \\
\text { medium } \\
\mathrm{NaH}^{13} \mathrm{CO}_{3}\end{array}$} & \multirow{2}{*}{$\begin{array}{c}\text { Initial concentration } \\
(\mu \mathrm{M}) \text { of labelled } \\
\text { compounds in the } \\
\text { incubation medium }\end{array}$} & \multicolumn{2}{|c|}{$\begin{array}{c}\text { Final concentration } \\
(\mu \mathrm{M}) \text { obtained after } \\
1 \mathrm{~h} \text { in bacteria and } \\
\text { shrimps tissues }\end{array}$} \\
\hline & & MP & $157.17 \pm 52.92$ \\
\hline & & $\mathrm{DT}$ & $49.94 \pm 0.29$ \\
\hline & & BB & $42.04 \pm 13.84$ \\
\hline & & $\mathrm{Mu}$ & $20.42 \pm 9.13$ \\
\hline & & OB & $8.30 \pm 7.33$ \\
\hline \multirow{8}{*}{$\mathrm{NaH}^{14} \mathrm{CO}_{3}$} & 3000 & MP & $33.01 \pm 16.31$ \\
\hline & & OB & $19.88 \pm 15.13$ \\
\hline & & DT & $15.84 \pm 16.30$ \\
\hline & & BB & $12.20 \pm 4.89$ \\
\hline & & $\mathrm{AC}$ & $7.02 \pm 2.95$ \\
\hline & & $\mathrm{Gi}$ & $5.97 \pm 2.04$ \\
\hline & & $\mathrm{HP}$ & $2.13 \pm 0.55$ \\
\hline & & $\mathrm{Mu}$ & $1.75 \pm 1.01$ \\
\hline \multirow[t]{11}{*}{${ }^{14} \mathrm{C}$-acetate } & 200 & MP & $524.24 \pm 100.53$ \\
\hline & & BB & $281.48 \pm 47.86$ \\
\hline & & $\mathbf{G i}$ & $245.47 \pm 66.43$ \\
\hline & & OB & $111.52 \pm 53.91$ \\
\hline & & $\mathrm{AC}_{\mathrm{n}}$ & $101.97 \pm 80.37$ \\
\hline & & $\mathrm{U}$ & $46.19 \pm 9.14$ \\
\hline & & AC & $33.01 \pm 0.35$ \\
\hline & & DT & $18.79 \pm 9.61$ \\
\hline & & $\mathrm{AC}_{\mathrm{o}}$ & $14.87 \pm 0.91$ \\
\hline & & $\mathrm{Mu}$ & $9.01 \pm 3.76$ \\
\hline & & $\mathrm{HP}$ & $7.84 \pm 0.99$ \\
\hline \multirow[t]{7}{*}{${ }^{3} \mathrm{H}$-lysine } & 0.2 & MP & $14.82 \pm 7.92$ \\
\hline & & BB & $3.02 \pm 2.97$ \\
\hline & & Gi & $0.54 \pm 0.28$ \\
\hline & & OВ & $0.48 \pm 0.22$ \\
\hline & & $\mathrm{Mu}$ & $0.06 \pm 0.00$ \\
\hline & & DT & $0.00 \pm 0.01$ \\
\hline & & $\mathrm{HP}$ & $0.00 \pm 0.00$ \\
\hline
\end{tabular}

Abbreviations: AC, abdominal cuticle; ACn, new abdominal cuticle; $\mathrm{AC}_{\mathrm{o}}$, old abdominal cuticle; $\mathrm{BB}$, branchiostegite biofilm; DT, digestive tract; Gi, gills; HP, hepatopancreas; MP, mouthpart; Mu, muscles; $\mathrm{OB}$, outer branchiostegite; U, uropods.

In bold are the data for compartments that accumulate the radiotracers (in > out). For the comparative estimation of tissue concentrations, $1 \mathrm{~g}$ fresh weight was considered equal to $1 \mathrm{ml}$ liquid. All values are taken from experiments in pure seawater. 
carbon to shrimps. They are in good agreement with previous stable isotope studies (Gebruk et al., 1993; Pond et al., 1997a, b, 2000; Rieley et al., 1999; Colaço et al., 2007) and confirm that $R$. exoculata depends on its epibionts for its nutrition. They thus strengthen the view that the relationship between bacteria and shrimp is mutualistic: the epibionts supply carbon compounds to the shrimp and the shrimp, thanks to its gill chamber flow and its swimming behaviour, offers them protection and a supply of chemical compounds, maintaining their position at the oxic/anoxic interface around active chimneys (Casanova et al., 1993; Segonzac et al., 1993). The $R$. exoculata bacterial epibiosis can thus be regarded as a true mutualistic trophic ectosymbiosis, similar to what is known about the chemosynthetic endosymbiosis of organisms such as R. pachyptila (Felbeck, 1981; Fisher et al., 1989), Calyptogena magnifica (Childress et al., 1991) and S. velum (Stewart and Cavanaugh, 2006; Scott and Cavanaugh, 2007).

Finally, the view that bacterial products are assimilated across the shrimp integument rather than via the $D T$ is strongly supported by: (1) the significant incorporation of both ${ }^{14} \mathrm{C}$-acetate and ${ }^{3} \mathrm{H}$ lysine after an incubation time as short as $1 \mathrm{~h}$. This is insufficient for uptake by ingestion assimilation, which commonly takes several hours (ingestion assimilation of carbon from bicarbonate, for example, requires prior incorporation by the bacteria, followed by grazing of bacteria from the $M P$ ) (Chipps, 1998; Hoyt et al., 2000); (2) the high incorporation levels recorded in the gill chamber integument lining $(O B, G i)$, as opposed to (3) the much lower levels recorded in the DT (Figure 6). These results are in agreement with the view that the shrimps do not graze on their epibionts (Zbinden et al., 2004; Corbari et al., 2008b), but rather farm them (Segonzac et al., 1993; Polz and Cavanaugh, 1996), although they might also ingest some chimney bacteria along with sulphides (Van Dover et al., 1988; Segonzac, 1992). The low but nevertheless significant incorporation of ${ }^{14} \mathrm{C}$ from bicarbonate in the DT corroborates the data of Polz et al. (1998), although they found higher rates than ours (upon incubating isolated gut segments). This incorporation might be due to chemosynthetic activity of the midgut microbial community (Polz et al., 1998; Zbinden and Cambon-Bonavita, 2003; Durand et al., 2010), but this community would be less active than the gill chamber community.

The view that soluble carbon-containing compounds are transferred from bacteria to shrimp by crossing the gill chamber integument tallies with the ultrastructural characteristics of this integument, which resemble those of permeable and/or transporting tissues (Martinez et al., 2005): a very thin cuticle $(30 \mu \mathrm{m})$, reduced blood-water distance, mitochondria-rich cells with apical infolding in the branchiostegite epithelium. In $R$. exoculata, the uptake of bacterial nutrients across the integument
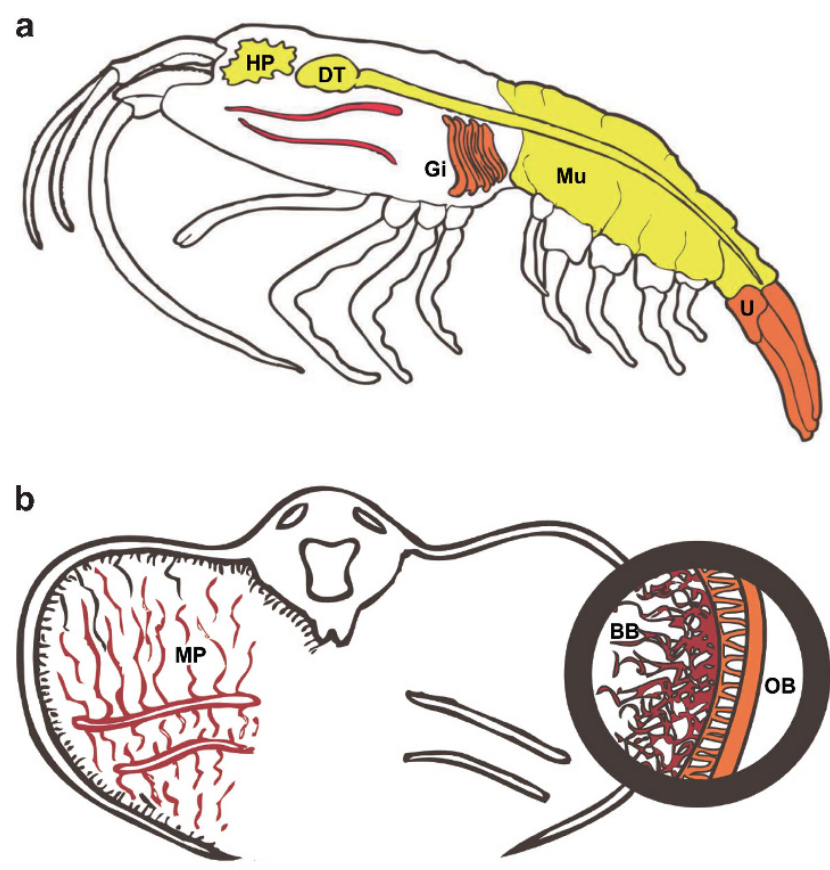

Figure 6 Schematic view of $R$. exoculata (a) and its gill chamber-transversal view (b) showing the level of ${ }^{14} \mathrm{C}$-tracers incorporation in the internal organs by colour range from the highest levels in red to the lowest in yellow. $U$, uropods.

could be the major source of nourishment, along with complementary sources such as grazing on chimney minerals (Van Dover et al., 1988; Segonzac et al., 1993), ingestion of bacteria-colonised exuviae, and midgut microflora activities (Zbinden and Cambon-Bonavita, 2003; Zbinden et al., 2004; Corbari et al., 2008b; Durand et al., 2010). It could be regarded as a peculiar adaptation of the shrimp. Although some authors have discarded this hypothesis, the present results may bring it back into favour. By extension, they suggest that this process might exist in many crustacean species, which would derive their nourishment at least partly from dissolved organic matter or dissolved organic carbon, as is commonly accepted for many marine invertebrates: annelids (Richards and Arme, 1982; Ahearn et al., 2000; Peppler and Ahearn, 2003), molluscs (Wright and Secomb, 1986; Wright, 1988; Wright and Pajor, 1989; De Eguileor et al., 2000) and cuticle-lined parasitic organisms such as nematodes (Fleming and Fetterer, 1984; Gordon and Burford, 1984; Masood, 1984). Arbitrarily rejected for crustaceans (Stephens, 1988) and especially decapods, this idea is surprisingly accepted without demonstration for parasitic rhizocephalan barnacles such as Sacculina carcini (Bresciani and Høeg, 2001) and for parasitic copepods (Kannupandi, 1976; Poquet et al., 1994) with a modified cuticle. It is well known, furthermore, that in pre-ecdysis, crustaceans (and other arthropods) absorb soluble molecules (for example, sugars and amino acids) from their degrading old cuticle through the new cuticle and re-utilise them for its synthesis (Compère et al., 
2004). These conflicting views regarding the capacity of marine crustaceans to assimilate dissolved organic carbon will be tested in further studies.

\section{Acknowledgements}

We thank F Gaill, chief scientist of the MoMARDREAMNaut cruise, the captain and crew of the RV 'Pourquoi Pas?' and the 'Nautile' team. We thank N Decloux for excellent technical assistance, A Saussu for drawing the shrimp diagram, Mrs K Broman (KBrO Science and Communication SPRL, broman.translations@swing.be) for the English revision as well as the reviewers and the editorial board for their constructive comments. This work was funded by the European RTN-MOMARnet program and the Belgian National Fund for Scientific Research (FNRSFRFC, convention no. 2.4594.07.F). JP is a PhD student supported by an FNRS-FRIA fellowship (Belgium) and GL is associated researcher of the FRS-FNRS (Belgium).

\section{References}

Ahearn H, Ahearn G, Gomme J. (2000). Integumentary L-histidine transport in a euryhaline polychaete worm: regulatory roles of calcium and cadmium in the transport event. J Exp Biol 203: 2877-2885.

Anderson JW, Stephens GC. (1969). Uptake of organic material by aquatic invertebrates. VI. Role of epiflora in apparent uptake of glycine by marine crustaceans. Mar Biol 4: 243-249.

Bresciani J, Høeg JT. (2001). Comparative ultrastructure of the root system in Rhizocephalan barnacles (Crustacea: Cirripedia: Rhizocephala). J Morphol 249: 9-42.

Campbell BJ, Engel AS, Porter ML, Takai K. (2006). The versatile $\varepsilon$-proteobacteria: key players in sulphidic habitats. Nat Rev Microbiol 4: 458-468.

CAREX Identification of model organisms in extreme environments. CAREX - Workshop Report; 5 November 2010; Sasbachwalden (Black Forest) Germany http://www.carex-eu.org/.

Casanova B, Brunet M, Ségonzac M. (1993). L'impact d'une épibiose bactérienne sur la morphologie fonctionnelle de crevettes associées à l'hydrothermalisme Médio-Atlantique. Cah Biol Mar 34: 573-588.

Cavanaugh C, McKiness Z, Newton I, Stewart F. (2006). Marine Chemosynthetic Symbioses. In: Dworkin M, Falkow S, Rosenberg E, Schleifer K-H, Stackebrandt E (eds). The Prokaryotes. Springer Science + Business Media, Inc.: Singapore, pp 475-507.

Charlou J-L, Donval J-P, Fouquet Y, Jean-Baptiste P, Holm N. (2002). Geochemistry of high $\mathrm{H}_{2}$ and $\mathrm{CH}_{4}$ vent fluids issuing from ultramafic rocks at the Rainbow hydrothermal field ( $\left.36^{\circ} 14^{\prime} \mathrm{N}, \mathrm{MAR}\right)$. Chem Geol 191: 345-359.

Childress JJ, Fisher CR, Favuzzi JA, Sanders NK. (1991). Sulfide and carbon dioxide uptake by the hydrothermal vent clam, Calyptogena magnifica, and its chemoautotrophic symbionts. Physiol Zool 64: 1444-1470.

Chipps SR. (1998). Temperature-dependent consumption and gut-residence time in the opossum shrimp Mysis relicta. J Plankton Res 20: 2401-2411.

Colaço A, Desbruyères D, Guezennec J. (2007). Polar lipid fatty acids as indicators of trophic associations in a deep-sea vent system community. Mar Ecol 28: 15-24.

Compère P, Jeuniaux C, Goffinet G. (2004). The integument: morphology and biochemistry. In: Forest J, Van Vaupel Klein JC (eds). Treatise on Zoology, 1. Anatomy, Taxonomy and Biology, The Crustacea. vol. 1: Brill, Leiden, pp 59-144.

Corbari L, Cambon-Bonavita M-A, Long GJ, Grandjean F, Zbinden M, Gaill F et al. (2008a). Iron oxide deposits associated with the ectosymbiotic bacteria in the hydrothermal vent shrimp Rimicaris exoculata. Biogeosciences 5: 1295-1310.

Corbari L, Zbinden M, Cambon-Bonavita M-A, Gaill F, Compère P. (2008b). Bacterial symbionts and mineral deposits in the branchial chamber of the hydrothermal vent shrimp Rimicaris exoculata: relationship to moult cycle. Aquat Biol 1: 225-238.

Dattagupta S, Schaperdoth I, Montanari A, Mariani S, Kita N, Valley JW et al. (2009). A novel symbiosis between chemoautotrophic bacteria and a freshwater cave amphipod. ISME J 3: 935-943.

De Eguileor M, Leonardi MG, Grimaldi A, Tettamanti G, Fiandra L, Giordana B et al. (2000). Integumental amino acid uptake in a carnivorous predator mollusc (Sepia officinalis, Cephalopoda). Tissue Cell 32: 389-399.

Douville E, Charlou J-L, Oelkers EH, Bienvenu P, Jove Colon CF, Donval J-P et al. (2002). The rainbow vent fluids $\left(36^{\circ} 14^{\prime} \mathrm{N}, \mathrm{MAR}\right)$ : the influence of ultramafic rocks and phase separation on trace metal content in Mid-Atlantic Ridge hydrothermal fluids. Chem Geol 184: $37-48$.

Dubilier N, Bergin C, Lott C. (2008). Symbiotic diversity in marine animals: the art of harnessing chemosynthesis. Nat Rev Microbiol 6: 725-740.

Dubilier N, Mulders C, Ferdelman T, de Beer D, Pernthaler A, Klein M et al. (2001). Endosymbiotic sulphatereducing and sulphide-oxidizing bacteria in an oligochaete worm. Nature 411: 298-302.

Durand L, Zbinden M, Cueff-Gauchard V, Duperron S, Roussel EG, Shillito B et al. (2010). Microbial diversity associated with the hydrothermal shrimp Rimicaris exoculata gut and occurrence of a resident microbial community. FEMS Microbiol Ecol 71: 291-303.

Felbeck H. (1981). Chemoautotrophic potential of the hydrothermal vent tube worm, Riftia pachyptila jones (Vestimentifera). Science 213: 336-338.

Fisher CR, Childress JJ, Minnich E. (1989). Autotrophic carbon fixation by the chemoautotrophic symbionts of Riftia pachyptila. Biol Bull 177: 372-385.

Fleming MW, Fetterer RH. (1984). Ascaris suum: continuous perfusion of the pseudocoelom and nutrient absorption. Exp Parasitol 57: 142-148.

Gebruk AV, Pimenov NV, Savvichev AS. (1993). Feeding specialization of bresiliid shrimps in the TAG site hydrothermal community. Mar Ecol Prog Ser 98: 247-253.

Gebruk AV, Southward EC, Kennedy H, Southward AJ. (2000). Food sources, behaviour, and distribution of hydrothermal vent shrimps at the Mid-Atlantic Ridge. J Mar Biol Assoc UK 80: 485-499.

Gillan DC, Dubilier N. (2004). Novel epibiotic Thiothrix bacterium on a marine Amphipod. Appl Environ Microbiol 70: 3772-3775.

Gillan DC, Ribesse J, De Ridder C. (2004). The ironencrusted microbial community of Urothoe poseidonis (Crustacea, Amphipoda). J Sea Res 52: 21-32. 
Goffredi SK. (2010). Indigenous ectosymbiotic bacteria associated with diverse hydrothermal vent invertebrates. Environ Microbiol Rep 2: 479-488.

Goffredi SK, Jones WJ, Erhlich H, Springer A, Vrijenhoek RC. (2008). Epibiotic bacteria associated with the recently discovered Yeti crab, Kiwa hirsuta. Environ Microbiol 10: 2623-2634.

Gordon R, Burford IR. (1984). Transport of palmitic acid across the tegument of the entomophilic nematode Romanomermis culicivorax. J Nematol 16: 14-21.

Guri M, Durand L, Cueff-Gauchard V, Zbinden M, Crassous P, Shillito B et al. (2012). Acquisition of epibiotic bacteria along the life cycle of the hydrothermal shrimp Rimicaris exoculata. ISME J 6: 597-609.

Hoyt M, Fleeger JW, Siebeling R, Feller RJ. (2000). Serological estimation of prey-protein gut-residence time and quantification of meal size for grass shrimp consuming meiofaunal copepods. J Exp Mar Biol Ecol 248: 105-119.

Hügler M, Gärtner A, Imhoff JF. (2010). Functional genes as markers for sulfur cycling and $\mathrm{CO}_{2}$ fixation in microbial communities of hydrothermal vents of the Logatchev field. FEMS Microbiol Ecol 73: 526-537.

Hügler M, Petersen JM, Dubilier N, Imhoff JF, Sievert SM. (2011). Pathways of carbon and energy metabolism of the epibiotic community associated with the deep-sea hydrothermal vent shrimp Rimicaris exoculata. PLoS ONE 6: e16018.

Kannupandi T. (1976). Cuticular adaptations in two parasitic copepods in relation to their modes of life. J Exp Mar Biol Ecol 22: 235-248.

Kleiner M, Wentrup C, Lott C, Teeling H, Wetzel S, Young J et al. (2012). Metaproteomics of a gutless marine worm and its symbiotic microbial community reveal unusual pathways for carbon and energy use. Proc Natl Acad Sci 109: E1173-E1182.

Larkin JM, Strohl WR. (1983). Beggiatoa, Thiothrix, and Thioploca. Annu Rev Microbiol 37: 341-367.

Lepoint G, Gobert S, Dauby P, Bouquegneau J-M. (2004). Contributions of benthic and planktonic primary producers to nitrate and ammonium uptake fluxes in a nutrient-poor shallow coastal area (Corsica, NW Mediterranean). J Exp Mar Biol Ecol 302: 107-122.

Macpherson E, Jones WJ, Segonzac M. (2005). A new squat lobster family of Galatheoidea (Crustacea, Decapoda, Anomura) from the hydrothermal vents of the PacificAntarctic Ridge. Zoosystema 27: 709-723.

Martinez A-S, Charmantier G, Compère P, CharmantierDaures M. (2005). Branchial chamber tissues in two caridean shrimps: the epibenthic Palaemon adspersus and the deep-sea hydrothermal Rimicaris exoculata. Tissue Cell 37: 153-165.

Masood K. (1984). Transcuticular absorption of amino acids by Ascaridia galli. Indian J Parasitol 7: 185-188.

Miyake H, Kitada M, Tsuchida S, Okuyama Y, Nakamura K-i. (2007). Ecological aspects of hydrothermal vent animals in captivity at atmospheric pressure. Mar Ecol 28: 86-92.

Nelson DC, Hagen KD, Edwards DB. (1995). The gill symbiont of the hydrothermal vent mussel Bathymodiolus thermophilus is a psychrophilic, chemoautotrophic, sulfur bacterium. Mar Biol 121: 487-495.

Peppler JE, Ahearn GA. (2003). Effect of heavy metals on the uptake of $[3 \mathrm{H}]$-L-histidine by the polychaete
Nereis succinea. Comp Biochem Physiol C Toxicol Pharmacol 136: 181-189.

Petersen JM, Ramette A, Lott C, Cambon-Bonavita M-A, Zbinden M, Dubilier N. (2009). Dual symbiosis of the vent shrimp Rimicaris exoculata with filamentous gamma- and epsilonproteobacteria at four Mid-Atlantic Ridge hydrothermal vent fields. Environ Microbiol 12: 2204-2218.

Petersen JM, Zielinski FU, Pape T, Seifert R, Moraru C, Amann $\mathrm{R}$ et al. (2011). Hydrogen is an energy source for hydrothermal vent symbioses. Nature 476: 176-180.

Polz MF, Cavanaugh CM. (1995). Dominance of one bacterial phylotype at a Mid-Atlantic Ridge hydrothermal vent site. Proc Natl Acad Sci USA 92: 7232-7236.

Polz MF, Cavanaugh CM. (1996). The ecology of ectosymbiosis at a Mid-Atlantic Rigde hydrothermal vent site. Biosyst Ecol Ser 11: 337-352.

Polz MF, Robinson JJ, Cavanaugh CM, Van Dover CL. (1998). Trophic ecology of massive shrimp aggregations at a Mid-Atlantic Ridge hydrothermal vent site. Limnol Oceanogr 43: 1631-1638.

Pond DW, Bell MV, Dixon DR, Fallick AE, Sargent JR. (1997a). Occurrence of 16:2(n-4) and 18:2(n-4) fatty acids in the lipids of the hydrothermal vent shrimp Rimicaris exoculata: nutritional and trophic implications. Marine Ecology Progress Series 156: 167-174.

Pond DW, Gebruk A, Southward EC, Southward AJ, Fallick AE, Bell MV et al. (2000). Unusual fatty acid composition of storage lipids in the bresilioid shrimp Rimicaris exoculata couples the photic zone with MAR hydrothermal vent sites. Mar Ecol Prog Ser 198: 171-179.

Pond DW, Segonzac M, Bell MV, Dixon DR, Fallick AE, Sargent JR. (1997b). Lipid and lipid carbon stable isotope composition of the hydrothermal vent shrimp Mirocaris fortunata: evidence for nutritional dependence on photosynthetically fixed carbon. Mar Ecol Prog Ser 157: 221-231.

Poquet M, Ribes E, Bozzo MG, Durfort M. (1994). Ultrastructure and cytochemistry of the integument of Modiolicola gracilis, parasitic copepod in mussel gills (Mytilus galloprovincialis and Mytilus edulis). J Morphol 221: 87-99.

Preston RL. (1993). Transport of amino acids by marine invertebrates. J Exp Zool 265: 410-421.

Ravaux J, Gaill F, Le Bris N, Sarradin P-M, Jollivet D, Shillito B. (2003). Heat-shock response and temperature resistance in the deep-sea vent shrimp Rimicaris exoculata. J Exp Biol 206: 2345-2354.

Richards KS, Arme C. (1982). Integumentary uptake of dissolved organic materials by earthworms. Pedobiologia 23: 358-366.

Rieley G, Van Dover CL, Hedrick DB, Eglinton G. (1999). Trophic ecology of Rimicaris exoculata: a combined lipid abundance/stable isotope approach. Mar Biol 133: 495-499.

Robidart JC, Bench SR, Feldman RA, Novoradovsky A, Podell SB, Gaasterland T et al. (2008). Metabolic versatility of the Riftia pachyptila endosymbiont revealed through metagenomics. Environ Microbiol 10: $727-737$.

Rouwenhorst RJ, Frank Jzn J, Scheffers WA, Van Dijken JP. (1991). Determination of protein concentration by total organic carbon analysis. J Biochem Biophys Methods 22: $119-128$ 
Schmidt C, Corbari L, Gaill F, Le Bris N. (2009). Biotic and abiotic controls on iron oxyhydroxide formation in the gill chamber of the hydrothermal vent shrimp Rimicaris exoculata. Geobiology 7: 454-464.

Schmidt C, Vuillemin R, Le Gall C, Gaill F, Le Bris N. (2008). Geochemical energy sources for microbial primary production in the environment of hydrothermal vent shrimps. Mar Chem 108: 18-31.

Schulz HN, Jørgensen BB. (2001). Big Bacteria. Annu Rev Microbiol 55: 105-137.

Scott KM, Cavanaugh CM. (2007). $\mathrm{CO}_{2}$ uptake and fixation by endosymbiotic chemoautotrophs from the Bivalve Solemya velum. Appl Environ Microbiol 73: 1174-1179.

Segonzac M. (1992). The hydrothermal vent communities of Snake Pit area (Mid-Atlantic Ridge; $23^{\circ} \mathrm{N}, 3480 \mathrm{~m}$ ): megafaunal composition and microdistribution. Mar Biol 314: 593-600.

Segonzac M, De Saint Laurent M, Casanova B. (1993). L'énigme du comportement trophique des crevettes Alvinocarididae des sites hydrothermaux de la dorsale médio-atlantique. Cah Biol Mar 34: 535-571.

Shillito B, Jollivet D, Sarradin P-M, Rodier P, Lallier F, Desbruyères D et al. (2001). Temperature resistance of Hesiolyra bergi, a polychaetous annelid living on deep-sea vent smoker walls. Mar Ecol Prog Ser 216: 141-149.

Stams AJM, Plugge CM. (2009). Electron transfer in syntrophic communities of anaerobic bacteria and archaea. Nat Rev Microbiol 7: 568-577.

Stephens GC. (1988). Epidermal amino acid transport in marine invertebrates. Biochim Biophys Acta 947: 113-138.

Stewart FJ, Cavanaugh CM. (2006). Bacterial endosymbioses in Solemya (Mollusca: Bivalvia) - model systems for studies of symbiont-host adaptation. Antonie Van Leeuwenhoek 90: 343-360.

Thurber AR, Jones WJ, Schnabel K. (2011). Dancing for food in the Deep Sea: bacterial farming by a new species of yeti crab. PLoS ONE 6: e26243.
Ullberg S, Larsson B, Tjälve H. (1982). Autoradiography. In: Glenn HJ (ed). Biologic Applications of Radiotracers. CRC Press: Boca Raton, Florida pp 55-108.

Van Dover CL, Fry B, Grassle JF, Humphris S, Rona PA. (1988). Feeding biology of the shrimp Rimicaris exoculata at hydrothermal vents on the Mid-Atlantic Ridge. Mar Biol 98: 209-216.

Williams AB, Rona PA. (1986). Two new caridean shrimps (Bresiliidae) from a hydrothermal field on the MidAtlantic Ridge. J Crust Biol 6: 446-462.

Wirsen CO, Jannasch HW, Molyneaux SJ. (1993). Chemosynthetic microbial activity at Mid-Atlantic Ridge hydrothermal vent sites. J Geophys Res 98: 9693-9703.

Wright SH. (1988). Amino acid transport in the gill epithelium of a marine bivalve. Comp Biochem Physiol A Physiol 90: 635-641.

Wright SH, Pajor AM. (1989). Mechanisms of integumental amino acid transport in marine bivalves. Am J Physiol 257: R473-R483.

Wright SH, Secomb TW. (1986). Epithelial amino acid transport in marine mussels: role in net exchange of taurine between gills and sea water. J Exp Biol 121: 251-270.

Zbinden M, Cambon-Bonavita M-A. (2003). Occurrence of Deferribacterales and Entomoplasmatales in the deepsea Alvinocarid shrimp Rimicaris exoculata gut. FEMS Microbiol Ecol 46: 23-30.

Zbinden M, Le Bris N, Gaill F, Compère P. (2004). Distribution of bacteria and associated minerals in the gill chamber of the vent shrimp Rimicaris exoculata and related biogeochemical processes. Mar Ecol Prog Ser 284: 237-251.

Zbinden M, Shillito B, Le Bris N, De Villardi de Montlaur C, Roussel E, Guyot F et al. (2008). New insights on the metabolic diversity among the epibiotic microbial communitiy of the hydrothermal shrimp Rimicaris exoculata. J Exp Mar Biol Ecol 359: 131-140.

Supplementary Information accompanies the paper on The ISME Journal website (http://www.nature.com/ismej) 